\title{
СОСТАВ АМИНОКИСЛОТ ЗЕЛЕНЫХ И ДИАТОМОВЫХ МИКРОВОДОРОСЛЕЙ, ЦИАНОБАКТЕРИЙ И ЗООПЛАНКТОНА (ОБЗОР)
}

\author{
А.А. Колмакова ${ }^{1}$, В.И. Колмаков ${ }^{1,2}$ \\ ${ }^{1}$ Институт биофизики СО РАН \\ 660036 Красноярск, Академгородок 50/50 \\ E-mail: angelika_@inbox.ru \\ ${ }^{2}$ Сибирский федеральный университет \\ 660041 Красноярск, пр. Свободный, 79 \\ E-mail: vkolmakov@sfu-kras.ru
}

Проведен анализ зарубежной и отечественной литературы, посвященной изучению состава аминокислот водных организмов, представляющих основные группы продуцентов (зеленые и диатомовые микроводоросли, цианобактерии) и первичных консументов (зоопланктон). На основе литературных данных представлены расчеты процентного состава заменимых и незаменимых аминокислот микроводорослей, цианобактерий, зоопланктона и определены их различия. Сделан вывод о неоднородности процентного состава аминокислот основных групп планктона. Обсуждена роль аминокислот как лимитирующего фактора развития растительноядного зоопланктона. Показаны перспективы и необходимость дальнейшего изучения состава аминокислот для разработки полной теории функционирования водных экосистем.

Ключевые слова: аминокислоты, микроводоросли, цианобактерии, зоопланктон, водные экосистемы. 
ВВЕДЕНИЕ

Как известно, биологическая роль аминокислот (АК) в водном организме значительна и многообразна [48, 66]. АК - это своеобразные “интеграторы” основных метаболических процессов, занимающие центральное место в азотистом обмене, синтезе белков, нуклеиновых кислот, ферментов, гормонов и других биологически активных веществ, а также важнейший источник энергии для внутренних химических реакций. При этом длительное время считалось, что избыток АК распадается с выделением необходимой для жизнедеятельности энергии, а основная часть АК используются для синтеза и ресинтеза биологически важных веществ и белков. Современные представления о функциональной роли АК основаны на том, что отдельные аминокислоты играют роль самостоятельных регуляторов жизненно важных процессов, например, осмотического равновесия, репродукции, антиоксидазной активности и др. Очевидно, что человеку, как терминальному консументу продукции водных экосистем, важно знать состав АК основных гидробионтов, жизнедеятельность которых определяет функционирование целого водоема [3].

Пионерские исследования АК планктона, как важнейшей биохимической составляющей, были выполнены классиками мировой гидробиологии и основателями знаменитой Висконсинской школы лимнологов Бёрджем и Джудэем [13]. Следует отметить, что в то время методы изучения АК с использованием цветных реакций были весьма трудоемкими и не обеспечивали необходимую точность измерений. В сороковых годах прошлого века для определения состава АК стали использовать метод бумажной хроматографии, разработанный Консдэном, Гордоном и Мартином [17]. Применение данного метода не только повысило достоверность результатов, но и позволило анализировать новые аминокислоты, которые не могли быть определены ранее. На тот период приходится большое количество публикаций, посвященных определению состава АК пресноводных 4 микроводорослей [65, 25], в том числе, в таких высокорейтинговых журналах, как Nature [24]. 
55 Дальнейший прогресс в исследованиях АК произошел с развитием и внедрением в практику 56 метода ионообменной хроматографии, и, особенно, после создания автоматического анализатора [60], когда заметно возросла оперативность и чувствительность определения АК.

Процесс совершенствования методик определения АК продолжается до сих пор [57].

Традиционно, большая часть публикаций по изучению АК, приходится на виды гидробионтов, представляющие коммерческий интерес в пищевой, сельскохозяйственной и медицинской области $[32,50,9]$. Наряду с этим, в последние годы приобретают актуальность сравнительные исследования состава АК на различных трофических уровнях [46], что связано с изменениями как в представлениях о функциональной роли АК, так и во взглядах на трофометаболические взаимодействия продуцентов и консументов в целом [23]. Так было показано, во-первых, что АК могут выступать как лимитирующий фактор для развития первичных консументов [10]. Во-вторых, состав АК в пище оказывает влияние на размножение беспозвоночных животных [30, 37]. В-третьих, некоторые аминокислоты (например, аргинин и гистидин) вовлечены в запуск механизма перехода между типами размножения у дафний [45].

Задача настоящей работы - систематизировать данные о составе аминокислот основных продуцентов водных экосистем (микроводоросли и цианобактерии) и первичных консументов (зоопланктон), а также обсудить возможную роль АК как потенциального лимитирующего фактора для развития растительноядного зоопланктона. Постановка данной задачи определяется тем, что знания о составе АК живых организмов, а также роли АК в пищевых взаимодействиях продуцентов и первичных консументов, необходимы для понимания закономерностей образования и направления потоков органического вещества в водоемах. Это связано с тем, что АК являются не только строительными блоками белков, но и служат в качестве предшественников биосинтеза некоторых важных органических веществ. 


\section{ОБЩИЕ ПРЕДСТАВЛЕНИЯ ОБ АМИНОКИСЛОТАХ ГИДРОБИОНТОВ}

В клетках водных организмов аминокислоты могут находиться как в “свободном”, так и в “связанном” (входят в состав белка) виде. Хотя суммарное содержание свободных АК составляет, как правило, менее $10 \%$ от суммарного содержания внутриклеточных АК, они могут выполнять функции в водном организме, которые отличаются от функций связанных АК [33]. В настоящей работе обсуждаются результаты исследований как общего содержания аминокислот в гидробионтах, т.е. связанных и свободных АК, так и отдельно свободных аминокислот. Как правило, авторы ограничиваются определением только 17 АК, выполняющих основную роль в синтезе белков, а при изучении состава свободных АК обычно определяют 18 (дополнительно глутамин (Глн)). Аминокислоты, являющиеся промежуточными метаболитами в клетке (орнитин, таурин, $\gamma$-аминомасляная кислота и др.) и часто определяемые в составе растворенного органического вещества [4], в исследованиях с гидробионтами, как правило, не рассматриваются.

В зависимости от функции АК в белковом обмене, их принято делить на две категории: заменимые (аргинин (Арг), аспарагиновая кислота (Асп), серин (Сер), глутаминовая кислота (Глу), пролин (Про), глицин (Гли), аланин (Ала), цистеин (Цис), тирозин (Тир)) и незаменимые (валин (Вал), изолейцин (Иле), лейцин (Лей), фенилаланин (Фен), лизин (Лиз), метионин (Мет), треонин (Тре), гистидин (Гис)). Незаменимыми считаются те АК, которые не синтезируются животным организмом и должны поставляться в готовом виде с пищей. Исключение из пищевого рациона хотя бы одной из таких АК, при сохранении содержания остальных, влечет за собой задержку роста и снижение массы тела растущего животного организма. Заменимые АК синтезируются животными организмами и выполняют разнообразные функции, поэтому их роль не менее важна, чем незаменимых. В последнее десятилетие стали выделять условно незаменимые АК [48]. К ним часто относят аргинин, глицин, тирозин, пролин и глутаминовую кислоту, то есть те заменимые АК, которые 
105 синтезируются водными животными, однако скорость их утилизации выше скорости

106 внутреннего синтеза. Восполнение условно незаменимых АК также происходит за счет пищи.

107 Незаменимость АК устанавливается с учетом всех биохимических особенностей белкового

108 обмена данного вида гидробионта, его возраста и репродуктивного состояния.

109 Для сравнения аминокислотных профилей организмов разных трофических уровней и

110 видов используется понятие “процентный состав”, где содержание каждой аминокислоты

111 приводится в процентах от суммарного содержания аминокислот. Содержание АК в

112 гидробионтах описано в литературе несколькими способами. Преобладающими способами

113 выражения содержания отдельной АК являются: 1) процент от суммы аминокислот; 2)

114 процент от сухого веса; 3) процент от общего углерода; 4) процент от общего азота. Очевидно,

115 что ни одно выражение не является универсальным и выбирается автором в зависимости от

116 цели исследования. Однако это многообразие способов выражения содержания АК

117 существенно затрудняет их сравнивание. К тому же не всегда в литературе приводится

118 достаточно данных для взаимной конвертации значений (влажность, содержание азота,

119 углерода). Поэтому для сравнения состава АК были отобраны данные только из тех

120 публикаций, в которых была возможность пересчета в процент от суммы АК.

121

АМИНОКИСЛОТЫ МИКРОВОДОРОСЛЕЙ И ЦИАНОБАКТЕРИЙ

Состав и содержание АК фитопланктона и перифитона в основном определяется

124 цианобактериями, зелеными и диатомовыми микроводорослями. При этом традиционно

125 принято рассматривать состав АК (заменимых и незаменимых) микроводорослей и

126 цианобактерий как однообразный и неизменный, особенно по сравнению с другими

127 биохимическими компонентами, такими как, биогенные элементы (C, N, P), стерины и

128 незаменимые полиненасыщенные жирные кислоты семейства $\omega 3$ [7, 34, 40]. Однако

129 планомерных экспериментальных и теоретических работ по сравнительному изучению состава 
130 АК микроводорослей и цианобактерий в литературе мало, а гипотеза об однообразии состава

131 АК требует дополнительной проверки.

132 Сводные данные по процентному составу незаменимых и заменимых АК

133 цианобактерий, зеленых и диатомовых микроводорослей представлены в таблицах 1 и 2 . Из

134 них следует, что нет различий в суммарном содержании $(M \pm m)$ незаменимых $A K$ y

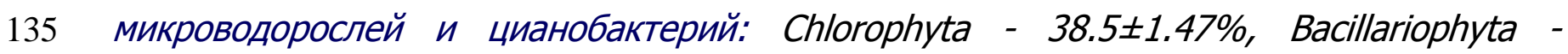

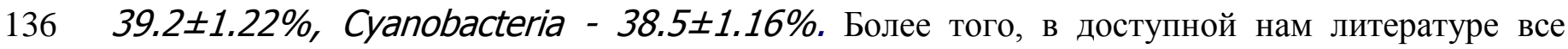

137 результаты экспериментальных определений суммарного содержания незаменимых АК

138 лабораторных культур или природных популяций микроводорослей и цианобактерий

139 укладывались в промежуток от 35\% до 45\%. Т.е. суммарный состав незаменимых АК обладает

140 стабильностью.

141 Общим для профиля незаменимых АК микроводорослей и цианобактерий является

142 высокое содержание лейцина, а также низкое содержание метионина и гистидина (табл.1).

143 Достоверных различий в составе незаменимых АК зеленых и диатомовых

144 микроводорослей не обнаружено.

145 У цианобактерий, по сравнению с зелеными и диатомовыми микроводорослями,

146 обнаружено более низкое содержание лизина $(\mathrm{p}<0.05)$. Лизин - важнейший субстрат для

147 синтеза карнитина, который обеспечивает транспорт длинноцепочечных жирных кислот

148 внутрь митохондрий, а также снижает воздействие токсичности, например, аммония и

149 ксенобиотиков. Нельзя исключать, что одной из причин слабого развития зоопланктона в

150 периоды “цветения” воды является недостаток содержания лизина в “цианобактериальной”

151 пище. Тем более, что доминирование цианобактерий в отдельном водоеме может

152 продолжаться более двух месяцев, а суммарное содержание АК цианобактерий составлять до $15335 \%$ от общей органической биомассы водоема [1]. 
Из табл. 1 также следует, что цианобактерии содержат достоверно (p<0.05) больше

155 валина, чем диатомовые микроводоросли. Важно отметить, что заметное различие в

156 содержании валина было обнаружено как при сравнении диатомеи Stephanodiscus sp. и

157 цианобактерии Aphanizomenon flos-aquae (L.) Ralfs. из одного сибирского водоема [41], так и

158 при сравнении диатомовых из малазийских водоемов [52] с цианобактерией Spirulina sp. из

159 африканского озера Чад [32]. Вероятно, повышенное содержание валина у цианобактерий не

160 связано с влиянием географических или сезонных факторов, а определяется их

161 физиологическими особенностями. Несмотря на то, что валин давно открыт и много изучается,

162 его физиологическая роль у гидробионтов, за исключением строительства белковых молекул и

163 стимулирования роста, до сих пор окончательно не установлена.

164 Кроме этого, цианобактерии содержат достоверно $(\mathrm{p}<0.05)$ больше изолейцина и

165 меньше гистидина, чем зеленые микроводоросли. В литературе приводятся сведения о

166 функциях и ответственной роли, которую выполняет гистидин для нормального

167 функционирования водных первичных консументов [2]. Поэтому недостаток гистидина в

168 “цианобактериальной” пище также может быть причиной лимитирования роста животных

169 гидробионтов. Изолейцин, как и валин, относится к особым аминокислотам, имеющим в

170 химической структуре разветвленную боковую цепь с атомами углерода и кислорода.

171 Возможно, уникальное строение изолейцина и объясняет ту ключевую роль, которую

172 выполняет данная АК при утилизации пищи животными организмами.

173 Общепризнано, что для цианобактерий и микроводорослей характерно наличие в

174 гидролизатах клеток относительно большого количества заменимых глутаминовой и

175 аспарагиновой кислоты, доля каждой из которых часто превышает 10\% от суммы всех АК, и

176 малого количества тирозина. Как правило, относительно высокое содержание среди

177 заменимых АК также приходится на аланин, глицин и аргинин, что и подтверждается данными

178 из табл.2. 
Из табл. 2 следует, что цианобактерии имеют повышенное содержание аспарагиновой

180 кислоты и серина по сравнению с Chlorophyta. Обе аминокислоты выполняют важные

181 регуляторные функции у гидробионтов и знания о них постоянно пополняются. Например,

182 недавно было установлено, что генномодифицированный штамм цианобактерии Synechocystis

183 sp., у которого на определенных участках серин был замещен на другие АК, обладал

184 устойчивостью к повышенным температурам [21]. Среди всех заменимых АК, только по

185 содержанию серина обнаружены различия между представителями зеленых и диатомовых

186 микроводорослей (табл.2). Сравнение состава заменимых АК цианобактерий и диатомовых

187 микроводорослей показало, что различий между ними нет.

188 В литературе имеются данные, свидетельствующие в пользу видоспецифичности

189 состава АК микроводорослей внутри одной таксономической группы. Например, Кхатун с

190 соавторами [42] выявили, что диатомовые микроводоросли рода Amphora содержали более

191 высокое количество таких незаменимых АК, как аргинин, треонин, тирозин, лизин,

192 фенилаланин и валин по сравнению с диатомеями рода Navicula и Cymbella. Относительно

193 высокое содержание лизина и изолейцина среди Bacillariophyta обнаружено у Chaetoceros

194 calcitrans (Paulsen) Takano 1968 [28]. По данным Брауна и Джеффри [14] Micromonas pusilla

195 (Butcher) Manton \& Parke, 1960 (Chlorophyta) содержала на 1/4 меньше аргинина, чем другие

196 виды зеленых микроводорослей. Относительно высокое содержание треонина и феналаланина

197 среди Chlorophyta обнаружено у Tetraselmis suecica (Kylin) Butcher [28].

198 Следует отметить, что в настоящее время много внимания уделяется вопросу изучения

199 зависимости состава АК лабораторных культур микроводорослей и цианобактерий от условий

200 культивирования $[53,56,64]$. На примере Chlorella sp. было показано, что состав АК оставался

201 стабильным при ее культивировании на естественном (outdoor) освещении и искусственном

202 (indoor) освещении в биореакторе [64]. Однако при культивировании хлореллы в темноте

203 (гетеротрофные условия) и на искусственном свету (автотрофные условия), были обнаружены 
204 достоверные различия по всем АК, кроме аланина [56]. Также зависимость состава АК от 205 условий культивирования была показана для цианобактерии Spirulina platensis (Nords.) Geilt. и зеленой микроводоросли Scenedesmus quadricauda (Turp) Breb. При их культивировании, 207 кроме фотопериода и интенсивности света, на состав АК могут влиять и такие факторы как 208 турбулентность, pH, соленость, температура, содержание биогенных элементов в среде. 209 Известна зависимость состава АК цианобактерии Anabena sp. от источника азота [1]. В литературе имеются противоречивые сведения по зависимости состава АК культур 211 диатомовых микроводорослей от условий выращивания. С одной стороны, в работе Брауна с 212 соавторами [15], указывается на отсутствие очевидной связи состава АК от фотопериода и 213 интенсивности света в лабораторных экспериментах с культурой диатомеи Thalassiosira 214 pseudonana Hasle \& Heimdal. С другой стороны, состав АК диатомей зависел от добавок азота 215 в среду [22]. Более того, еще в классической работе Хески с соавторами [35] на примере шести 216 видов диатомей было показано, что состав АК в клеточной стенке и внутри цитоплазмы может 217 заметно варьировать в зависимости от условий среды.

В природных условиях состав свободных АК микроводорослей может резко меняться в течение вегетационного периода. Например, было установлено значительное (до 20 раз) изменение внутриклеточной концентрации свободных АК у диатомовой микроводоросли Rhizosolenia delicatula Cleve в течение периода ее массового развития [49]. При этом 224 наибольшее содержание АК приходилось на глутаминовую кислоту, глутамин, аланин, 225 изолейцин и лизин, суммарное содержание которых превышало 65\%. В периоды, когда развития Rh. delicatula не происходило, у доминирующих планктонных микроводорослей преобладали другие АК: серин, глицин, аргинин и аспарагиновая кислота. 
Временная изменчивость состава свободных АК известна и для лабораторных культур

229 микроводорослей и цианобактерий. Так, по данным А.И. Сакевич и П.Д. Клоченко [4], в

230 начале экспоненциальной фазы роста цианобактерии Microcystis aeruginosa Kutz em. Elenk. и

231 зеленой микроводоросли Scenedesmus acuminatus (Lagerh.) Chodat в биомассе преобладали

232 свободные глутаминовая и аспарагиновая кислоты, глицин, аланин, валин, пролин, серин,

233 треонин и лейцин. По мере старения культур было отмечено снижение величины

234 внутриклеточного фонда свободных аминокислот и следовые количества гистидина, аргинина,

235 пролина и фенилаланина.

236 Состав свободных АК микроводорослей и цианобактерий обладает более выраженной

237 изменчивостью и «быстрыми» ответами на воздействие внешних факторов, чем состав

238 связанных АК. По данным Гранума с коллегами [27] внутриклеточное суммарное содержание

239 свободных АК диатомеи Skeletonema costatum (Grev.) Cleve заметно (на 90\%) уменьшалось в

240 течение суток при уменьшении концентрации неорганического азота в среде, а наибольшее

241 снижение наблюдалось для глутамина. По мнению Адмираала с соавторами [6] крупные по

242 размерам диатомеи могут выступать в качестве индикаторов обеспеченности азотом в среде,

243 так как при его недостатке содержат от 3 до 50 раз меньше АК, чем при обилии азота. Состав

244 АК у диатомовых микроводорослей также зависит от фазы роста культуры [68] и световых

245 условий [26]. Особенностью состава АК цианобактерий считаются различия у видов,

246 формирующих гетероцисты, по сравнению с видами, не имеющими гетероцист [47].

247 Состав свободных АК различается для отдельных таксономических групп

248 микроводорослей и цианобактерий. В экспериментах на чистых культурах было обнаружено,

249 что цианобактерии по сравнению с Chlorella sp., содержали более чем в пять раз больше

250 изолейцина, в четыре раза больше валина и лейцина, в три раза больше фенилаланина, и

251 наоборот, на два порядка меньше гистидина, в три раза меньше аргинина и более чем в два

252 раза меньше лизина [59]. В целом, у цианобактерий и хлореллы не было различий только по 
253

254

255

256

содержанию аланина и метионина. По предположению Соримачи [58], различия в составе внутриклеточных свободных АК цианобактерий и микроводорослей - это результат длительного эволюционного процесса прокариотических и эукариотических организмов.

\section{АМИНОКИСЛОТЫ ЗООПЛАНКТОНА}

Сводные данные по составу незаменимых и заменимых АК зоопланктона представлены в таблице 3 и 4. Если сравнить средние показатели состава АК зоопланктона с таковыми для микроводорослей и цианобактерий (см. табл.1,2), то можно отметить следующее. Во-первыX,

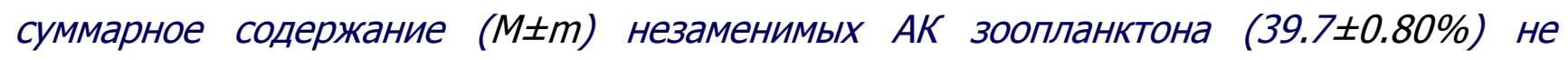
отличается от такового для микроводорослей и цианобактерий, а наибольшее содержание также приходится на аспарагиновую и глутаминовую кислоту. Во-вторых, по сравнению с цианобактериями зоопланктон содержит больше лизина, гистидина и пролина $(p<0.001)$, но меньше лейцина и серина $(p<0.05)$. В-третьих, зоопланктон отличается от зеленых микроводорослей более высоким относительным содержанием лизина и глутаминовой кислоты $(p<0.05)$. В-четвертых, зоопланктон содержит больше гистидина ( $<<0.001)$ и меньше серина $(\mathrm{p}<0.05)$, чем диатомеи. Т.е. полного совпадения состава АК зоопланктона с цианобактериями или одной из таксономических групп микроводорослей не обнаружено. Более того, различия были как среди состава незаменимых, так и заменимых АК. Считается, что внутривидовые и межвидовые различия в биохимических составах водных беспозвоночных животных менее выражены, чем таковые у автотрофных организмов [61], и состав АК зоопланктона не является исключением. Большинство авторов, проводивших исследования состава АК зоопланктона во второй половине XX века, описывали его как однообразный и неизменный при воздействии различных факторов среды $[18,19]$. В работе Гуисанде с коллегами [29] показано, что у самок копепод Euterpina acutifrons Dana, 1847 в течение года не было выявлено изменений в составе большинства незаменимых АК. 
Однако в современных публикациях все чаще делается вывод о существовании внутривидовых и межвидовых различий в составе АК зоопланктона $[54,67]$. Некоторые исследователи полагают, что состав АК зоопланктона не только предопределен генетически, но и зависит от влияния условий внешней среды [31], репродуктивных, половых и онтогенетических факторов [16], а также от условий питания [30]. Например, зависимость состава АК от качества пищи была показана на примере рачков Artemia sp. [51], Artemia 284 parthenogenetica, Bacigozzi 1974 и коловратки Brachionus rotundiformis Tschugunoff, 1921 [11]. 285 Наибольшие различия состава АК веслоногих ракообразных на разных стадиях онтогенеза были отмечены у каланоидов - Eurytemora velox Lilljebord, 1853 и Calanipeda aquae-dulcis Kritsch, 1873, а также циклопоидов - Diacyclops bicuspidatus odessanus Shmankevich, 1875 и 288 Acanthocyclops robustus Sars, 1863 [16]. Взрослые особи имели повышенное содержание 289 аланина, валина, глутаминовой кислоты, глицина, аргинина, пролина и тирозина, по сравнению с науплиями. У Daphnia pulicaria Forbes, 1893 изменение состава АК было связано с онтогенетическими изменениями, в отличие от веслоногого рачка Diaptomus cyaneus Gurney, 292 1909, чей состав АК в большей мере зависел от состояния репродукции [67]. Значительные 293 сезонные изменения в составе заменимых АК показаны для Parapenaeus longirostris Lucas, 294 1846, при этом состав незаменимых АК менялся незначительно [55]. Выявленные с помощью дискриминантного анализа достоверные различия в составе АК внутри нескольких видов кладоцер, циклопов, каланоидов и коловраток из озер, расположенных на разной высоте над уровнем моря, позволили Гуисанде [31] рассматривать состав АК зоопланктона как индикатор 298 трофической ниши и адаптации вида к абиотической среде. Известно, что недостаток незаменимых АК в пище отрицательно влияет на рост и 300 размножение растительноядного зоопланктона [29, 63]. Особое внимание исследователей 301 направлено на изучение потребностей в АК, к недостатку которых зоопланктонные организмы 302 особенно чувствительны, а именно, лизина, метионина, гистидина и аргинина [44]. В 
аквакультуре концентрации этих АК в рационе рассматриваются как наиболее важные показатели питательной ценности диеты, так как они влияет на скорость питания, рост, состав тела и морфометрические параметры зоопланктона. Исходя из установленной потребности в одной АК (обычно лизина), можно определять потребности в других АК для зоопланктона согласно известным пропорциям незаменимых АК. При оценке качества пищи относительно какой-либо незаменимой АК следует учитывать не только содержание этой АК в пище, но и ее доступность для переваривания.

Таким образом, на основании знаний о потребностях зоопланктонного организма в содержании незаменимых аминокислот в пище, можно рассчитать количество пищи, 312 необходимое для нормального развития, а также оценить качество микроводорослевых или 313 цианобактериальных ресурсов.

Состав свободных АК зоопланктона, также как микроводорослей и цианобактерий, 317 характеризуется большей “подвижностью”, чем состав связанных АК. При этом у 318 большинства видов зоопланктона, которые обитают в соленой воде, содержание свободных 319 АК в теле организма выше, чем у пресноводных видов. Это связано с тем, что в соленой среде 320 свободные АК необходимы водному организму для процессов осморегуляции [69, 28]. 321 Например, пул свободных аминокислот морской Parapenaeus longirostris составлял от 12 до 322 25\% от общего содержания аминокислот [55], а у пресноводных копепод от 2 до 5\% [20]. 323 Содержание свободных АК значительно увеличивалось у рачка Artemia sp., при переходе на 324 культивирование при высокой солености [36]. Состав свободных АК зоопланктона также зависит от времени года и стадии развития $326[37,38]$, количества и качества пищи $[36,11]$. Отмечено влияние сезонов на состав АК самок, 327 яиц и науплий Calanus finmarchicus Gunner, 1765 [39]. Содержание АК, особенно 
328 незаменимых, в самках, яйцах и науплиях было выше осенью, чем весной. Количество

329 свободных АК в копеподах Temora longicornis Muller, 1785 на единицу белка изменилось

330 почти в два раза в течение двух сезонов [38].

331 Между представителями отдельных таксономических группировок зоопланктона также

332 установлены различия в составе свободных АК. Например, содержание свободных

333 аминокислот было более высоким в коловратках Brachionus rotundiformis, чем в рачках Artemia

334 parthenogenetica, причем у коловраток доминировал аланин [11].

\section{ЗАКЛЮЧЕНИЕ}

Результаты проведенного анализа позволяют сделать вывод о специфичности состава

аминокислот зеленых и диатомовых микроводорослей, цианобактерий и зоопланктона.

339 Укрепившиеся в прошлом веке в журналах экологического профиля представления о полном

340 однообразии состава АК как продуцентов (микроводорослей и цианобактерий), так и

341 первичных консументов (зоопланктон) следует признать ошибочными.

342 Необходимо отметить, что современные знания о составе АК микроводорослей, 343 цианобактерий и зоопланктона сложились на основе изучения лабораторных культур (видов)

344 или штаммов (видов), выделенных из природных экосистем, а также отдельных природных 345 видов, доминирующих в составе планктона водной экосистемы. К сожалению, в литературе

346 почти нет работ, посвященных сравнительному изучению динамики состава АК основных

347 таксономических групп фитопланктона и зоопланктона в условиях континентального водоема,

348 а также экспериментов по поиску механизмов, приводящих к неоднородности состава АК. По

349 нашему мнению, такие мониторинговые исследования в сочетании с экспериментами в 350 контролируемых условиях являются наиболее актуальными и без них невозможно разработать 351 теорию о механизмах и особенностях формирования состава АК фитопланктона и 352 зоопланктона. 
Состав АК природных зеленых и диатомовых микроводорослей, цианобактерий и

354 зоопланктона зависит от условий окружающей среды, в первую очередь, таких как 355 вегетационный сезон, температура, содержание биогенных элементов, стадия жизненного 356 цикла. При этом наибольшее влияние биотические и абиотические факторы оказывают на 357 состав свободных АК, а не на связанные в белках АК.

358 Состав АК лабораторных культур микроводорослей и цианобактерий, а также 359 лабораторных видов зоопланктона зависит от условий культивирования. Следовательно, за 360 счет варьирования условий выращивания можно в промышленных масштабах получать 361 культуры, штаммы или виды с заданными параметрами по составу АК. В этой связи, 362 перспективным представляется направленный поиск высокопродуктивных штаммов, культур 363 или видов с высоким содержанием отдельных незаменимых АК.

364 Состав АК, наряду с биогенными элементами $(\mathrm{C}, \mathrm{N}, \mathrm{P})$, стеринами и незаменимыми 365 полиненасыщенными жирными кислотами, может играть ключевую роль в физиологии 366 организмов планктона и представлять собой незаменимый или дефицитный элемент питания 367 для животных, занимающих высшие уровни пищевой цепи водных экосистем. 
371 1. Горюнова С.В., Ржанова Г.Н., Орлананский В.Н. Синезеленые водоросли. Москва: Наука, 1969. 223 с.

2. Елякова Л.А., Светашова Т.Г., Лакизова И.Ю. Значение гистидина для активности $\beta-1,3-$ глюконазы IV из Spisula Sachalinensis // Биоорган. химия. 1977. Т. 3, № 3. С. 415-421.

3. Колмакова А.А., Гладышев М.И., Калачева Г.С. Различия аминокислотного состава доминирующих видов фитопланктона в эвтрофном водохранилище // Докл. АН. 2007. T.415, №5. C.711-713.

4. Сакевич А.И., Клоченко П.Д. Свободные аминокислоты в экологическом метаболизме водорослей // Гидробиологический журнал. 1996. Т. 32, № 5. С. 33-41.

380 5. Трубачев Н.И., Гительзон И.И., Калачева Г.С. и др. Биохимический состав некоторых сине-зеленых водорослей и хлореллы // Прикладная биохимия и микробиология. 1976. Т. 12, № 2. C. 196-202.

6. Admiraal W., Peletier H., Laame R.W.P.M. Nitrogen metabolism of marine planktonic diatoms: excretion, assimilation and cellular pools of free amino acid in seven species with different cell size // J. Exp. Mar. Biol. Ecol. 1986. V. 98, № 3. P. 241-263.

386 7. Ahlgren G., Gustafsson I.-B., Boberg M. Fatty acid content and chemical composition of freshwater microalgae // J. Phycol. 1992. V. 28, № 1. P. 37-50.

8. Ahlgren G., Hyenstrand P. Nitrogen limitation effects of different nitrogen sources on nutritional quality of two freshwater organisms, Scenedesmus quadricauda (Chlorophyceae) and Synechococcus sp. (Cyanophyceae) // J. Phycol. 2003. V. 39. P. 906-917.

9. Akgul R., Kizilkaya B., Akgul F., Erdugan H. Amino acid composition and crude protein values of some Cyanobacteria from Canakkale (Turkey) // Pak. J. Pharm. Sci. 2015. V. 28, № 5. P. 1757-1761. 
10. Anderson T.R., Boersma M., Raubenheimer D. Stoichiometry: linking elements to biochemicals // Ecology. 2004. V. 85. P. 1193-1202.

11. Aragao C., Conceicao L.E.C., Dinis M.T., Fuhn H.-J. Amino acid pool of rotifers and Artemia under different conditions: nutritional implications for fish larvae // Aquaculture. 2004. V. 234, № 1-4. P. 429-445.

12. Becker E. W. Micro-algae as a source of protein // Biotechnol. Adv. 2007. Vol. 25. P. 207-210.

13. Birge E.A., Juday C. The organic content of lake water // Proc. Nat. Acad. Sci. USA. 1926. V. 12, № 8. P. 515-519.

14. Brown M.R., Jeffrey S.W. Biochemical composition of microalgae from the green algal classes Chlorophyceae and Prasinophyceae. 1. Amino acids, sugars and pigments // J. Exp. Mar. Biol. Ecol. 1992. V. 161, № 1. P. 91-113.

15. Brown M. R., Dunstan G.A., Norwood S.J., Miller K.A. Effect of harvest stage and light on the biochemical composition of the diatom Thalassiosira pseudonana // J. Phycol. 1996. V. 32, № 1. P. 64-73.

16. Brucet S., Boix D., Lopez-Flores $R$. et al. Ontogenetic changes of amino acid composition in planktonic crustacean species // Mar. Biol. 2005. V. 48, № 1. P. 131-139.

17. Consden R., Gordon A.H., Martin A.J.P. Qualitative analysis of proteins: a partition chromatographic method using paper // Biochem. J. 1944. V. 38, № 3. P. 224-232.

18. Cowey C.B., Corner E.D.S. On the nutrition and metabolism of zooplankton II. The relationship between the marine copepod Calanus helgolandicus and particulate material in Plymouth sea water, in terms of amino acid composition // J. Mar. Biol. Ass. UK. 1963. V. 43. P. 495-511.

19. Cowgill U. M., Emmel H.W., Hopkins D.L. et al. Variation in chemical composition, reproductive success and body weight of Daphnia magna in relation to diet // Int. Rev. Ges. Hydr. Hydrogr. 1986. V. 71, № 1. P. 79-99. 
20. Dabrowski K., Rusiecki M. Content of total free amino acids in zooplanktonic food of fish larvae // Aquaculture. 1983. V. 30, № 1-4. P. 31-42.

21. Dinamarca J., Shlyk-Kerner O., Kaftan D. et al. Double mutation in photosystem II reaction centers and elevated $\mathrm{CO}_{2}$ grant thermotolerance to mesophilic Cyanobacterium // PLoS One. 2011. V. 6, № 12. P. 1-13.

22. Dortch $Q$. Effect of growth conditions on accumulation of internal nitrate, ammonium, amino acids and protein in three marine diatoms // J. Exp. Mar. boil. Ecol. 1982. V. 61, № 3. P. 243264.

23. Dubovskaya O.P., Klimova E.P., Kolmakov V.I. et al. Seasonal dynamic of phototrophic epibionts on crustacean zooplankton in a eutrophic reservoir with cyanobacterial bloom // Aquatic Ecol. 2005. V. 39, № 2. P. 167-180.

24. Fowden L. Amino-acids of certain algae // Nature. 1951. V.167. P.1030-1031.

25. Fowden L. A. A comparison of the compositions of some algal proteins // Ann. Botany. 1954. V. 18, № 71. P. 257-266.

26. Flynn K.J., Al-Amoudi O.A. Effects of $\mathrm{N}$ deprivation and darkness on composition of free amino acid release from diatom Phaeodactylum tricornutum Bohlin // J. Exp. Mar. Biol. Ecol. 1988. V. 119, № 2. P. 131-143.

27. Granum E., Kirkvold S., Myklestad S.M. Cellular and extracellular production of carbohydrates and amino acids by the marine diatom Skeletonema costatum: diel variations and effects of $\mathrm{N}$ depletion // Mar. Ecol. Progress Ser. 2002. V. 242. P. 83-84.

28. Guisande C., Maneiro I., Riveiro I. Homeostasis in the essential amino acid composition of the marine copepod Euterpina acutifrons // Limnol. Oceanogr. 1999. V. 44, № 3. P. 691-696.

29. Guisande C., Riveiro I., Maneiro I. Comparison among the amino acid composition of females, eggs and food to determine the relative importance of food quantity and food quality to copepod reproduction // Mar. Ecol. Prog. Ser. 2000. V. 202, № 1-4. P. 135-142. 
443 30. Guisande C., Bartumeus F., Ventura M., Catalan J. Role of food partitioning in structuring the zooplankton community in mountain lakes // Oecologia. 2003. V. 136, № 4. P. 627-634.

31. Guisande C. Biochemical fingerprints in zooplankton // Limnetica. 2006. V. 25, № 1-2. P. 369376.

32. Halawlaw Y.I. Spirulina microalgae: A food for future // Pinnacle Biotech. 2014. V. 1 (2). P. 249-255.

33. Hanson J.A., Dietz T.H. The role of free amino acids in cellular osmoregulation in the freshwater bivalve Ligumia subrostrata (Say) // Canadian J. Zool. 1976. V. 54, № 11. P. 19271931.

34. Hanamachi Y., Hama T., Yanai T. Decomposition process of organic matter derived from freshwater phytoplankton // Limnology. 2008. V. 9. P. 57-69.

35. Hecky R.E., Mopper K., Kilham P., E.T. Degens. The amino acid and sugar composition of diatom cell walls // Marine Biology. 1973. V. 19. P. 323 - 331.

36. Helland S., Triantaphullidis G., Fuhn H. et al. Modulation of the free pool and protein content in populations of the brine shrimp Artemia spp // Mar. Biol. 2000. V. 137, № 5. P. 1005-1016.

37. Helland S., Nejstgaard J.C., Humlen R. et al. Effects of season and material food on Calanus finmarchicus reproduction, with emphasis on the free amino acids // Mar. Biol. 2003a. V. 142, № 6. P. 1141-1151.

38. Helland S., Terjesen B., Berg L. Free amino acid and protein content in the planktonic copepod Temora longicornis compared to Artemia franciscana // Aquaculture. 2003b. V. 215, № 1-4. P. 213-228.

39. Helland S., Nejstgaard J.C., Humlen R. et al. Effects of starvation, season, and diet on the free amino acid and protein content of Calanus finmarchicus females // Mar. Biol. 2003c. V. 143, № 2. P. 297-306. 
40. Hempel N., Petrick I., Behrendt F. Biomass productivity and productivity of fatty acids and amino acids of microalgae strains as key characteristics of suitability for biodiesel production // J. Appl. Phycology. 2012. V. 24, № 6. P. 1407-1418.

41. Kalachova G.S., Kolmakova A.A., Gladyshev M.I. et al. Seasonal dynamics of amino acids in two small Siberian reservoirs dominated by prokaryotic and eukaryotic phytoplankton // Aquat. Ecol. 2004. V. 38. P. 3-15.

42. Khatoon H., Banerjee S., Yusoff F.M., Shariff M. Evaluation of indigenous marine periphytic Amphora, Navicula and Cymbella grown on substrate as feed supplement in Penaeus monodon postlarval hatchery system // Aquaculture Nutr. 2009. V. 15. P. 186-193.

43. Kibria G., Nugegoda D., Fairclough R. et al. Utilization of wastewater-grown zooplankton: Nutritional quality of zooplankton and performance of silver perch Bidyanus bidyanus (Mitchell 1838) (Teraponidae) fed on wasterwater-grown zooplankton // Aquaculture Nutr. 1999. V. 5, № 4. P. 221-227.

44. Kleppel G.S., Burkart C.A., Houchin L. Nutrition and the regulation of egg production in the calanoid copepod Acartia tonsa // Limnol. oceanogr. 1998. V. 43, №5. P. 1000 - 1007.

45. Koch U., Martin-Creuzburg D., Grossart H.-P., Straile D. Single dietary amino acids control resting egg production and affect population growth of a key freshwater herbivore // Oecologia. 2011. V. 167. P. 981-989.

46. Kolmakova A.A., Gladyshev M.I., Kalachova G.S. et al. Amino acid composition of epilithic biofilm and benthic animals in a large Siberian river // Freshwater Biol. 2013. V. 58, № 10. P. 2180-2195.

47. Laloraya V.K., Mitra A.K. Free amino acid composition of some nitrogen fixing blu-green algae in heterocystous and non-heterocystous condition // Experientia. 1970. V. 26, № 1. P. 39-40.

48. Li P., Mai K., Trushenski J., Wu G. New developments in fish amino acid nutrition: towards functional and environmentally oriented aquafeeds // Amino acids. 2009. V. 37. P. 43-53. 
49. Martin-Jezequel V., Sournia A., Birrien J.-L. A daily study of the diatom spring bloom at Roscoff (France) in 1985. III. Free amino acids composition studied by HPLC analysis // J. Plankton Res. 1992. V. 14, № 3. P. 409-421.

50. Misurcova L., Bunka F., Ambrozova J.V. et al. Amino acid composition of algal products and its contribution to RDI // Food Chem. 2014. V. 151. P. 120-125.

51. Mitra G. Mukhopadhyay P.K., Ayyappan S. Biochemical composition of zooplankton community grown in freshwater earthen ponds: Nutritional implication in nursery rearing of fish larvae and early juveniles // Aquaculture. 2007. V. 272, № 1-4. P. 346 - 360.

52. Natrah F.M., Yusoff F.M., Shariff M. et al. Screening of Malaysian indigenous microalgae for antioxidant properties and nutritional value // J. Appl. Phycol. 2007. V.19, № 6. P. 711-718.

53. Ogbonda K.H., Aminigo R.E., Abu G.O. Influence of temperature and $\mathrm{pH}$ on biomass production and protein biosynthesis in a putative Spirulina sp. // Bioresour. Technol. 2007. V. 98, № 11. P.2207-2211.

54. Ovie S.I., Ovie S.O. Moisture, protein, and amino acid contents of three freshwater zooplankton used as feed for aquacultured larvae and postlarvae // Isr. J. Aquaculture. 2006. V. 58, № 1. P. 29-33.

55. Rosa R., Nunes M.L. Seasonal patterns of nucleic acid concentrations and amino acid profiles of Parapenaeus longirostris (Crustacea, Decapoda): relation to growth and nutritional condition // Hydrobiologia. 2005. V. 537. P. 207 - 216.

56. Samek D., Misurcova L., Machu L. et al. Influencing of amino acid composition of green freshwater algae and cyanobacterium by methods of cultivation // Turk. J. Biochem. 2013. V. 38, № 4. P.360-368.

57. Shim Y.-S., Yoon W.-J., Ha J. et al. Method validation of 16 types of structural amino acids using an automated amino acid analyzer // Food Sci. Biotechnol. 2013. V. 22, № 6. P.15671571. 
517 58. Sorimachi $K$. Evolutionary changes reflected by the cellular amino acid composition // Amino Acids. 1999. V. 17. P. 207 - 226.

59. Sorimachi $K$. The classification of various organisms according to the free amino acid composition change as the result of biological evolution // Amino acids. 2002. V. 22. P. 55-69.

60. Spackman D.H., Stein W.H., Moore S. Automatic Recording Apparatus for Use in Chromatography of Amino Acids // Anal. Chem. 1958, V. 30, № 7. P. 1190-1206.

61. Sterner R.W., Hessen D.O. Algal nutrient limitation and the nutrition of aquatic herbivores // Ann. Rev. Ecol. System. 1994. V. 25. P. 1-29.

62. Tibbetts S. M., Milley J. E., Lall S. P. Chemical composition and nutritional properties of freshwater and marine microalgal biomass cultured in photobioreactors. // J Appl Phycol. 2015.

63. Wacker A., Martin-Creuzburg D. Biochemical nutrient requirements of the rotifer Brachionus calyciflorus: co-limitation by sterols and amino acids // Functional Ecology. 2012. V. 26, № 5.

64. Wang S.-K., Hu Y.-R., Wang F. et al. Scale-up cultivation of Chlorella ellipsoidea from indoor to outdoor in bubble column bioreactors // Bioresource Techn. 2014. V. 156. P. 117-122.

65. Williams A. E., Burris R. H. Nitrogen Fixation by Blue-Green Algae and Their Nitrogenous Composition // Am. J. Bot. 1952. V. 39, №. 5. P. 340-342.

66. $W u$ G. Functional amino acids in nutrition and health // Amino Acids. 2013. V. 45. P. 407-411.

67. Ventura M., Catalan J. Variability in amino acid composition of alpine crustacean zooplankton and its relationship with nitrogen-15 fractionation // J. Plankton Res. 2010. V. 32, № 11. P. 1583-1597.

68. Vidoudez C., Pohnert G. Comparative metabolomies of the diatom Skeletonema marinoi in different growth phases // Metabolomics. 2012. V. 8, № 4. P. 654-669. 
541 69. Yancey P.H. Clark M.E., Hand S.C. et al. Living with water stress: evolution of osmolyte

542 systems // Science. 1982. V. 217. P. $1214-1222$.

543

544

$545 \quad 07.11 .2016$

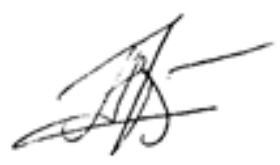

Колмакова A.A.

546

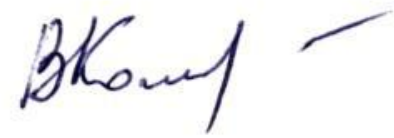

Колмаков В.И.

548

549

550 
Keywords: amino acids, microalgae, Cyanobacteria, zooplankton, aquatic ecosystem
AMINO ACIDS COMPOSITION OF GREEN MICROALGAE AND DIATOMS, CYANOBACTERIA AND ZOOPLANKTON (REVIEW)

\author{
A. A. Kolmakova ${ }^{1}$, V. I. Kolmakov ${ }^{1,2}$ \\ ${ }^{1}$ Institute of Biophysics Siberian Branch of RAS \\ 50/50 Akademgorodok, Krasnoyarsk, 660036, Russia \\ angelika_@inbox.ru \\ ${ }^{2}$ Siberian Federal University \\ 79 Svobodny Av, Krasnoyarsk, 660041, Russia \\ vkolmakov@sfu-kras.ru
}

We reviewed foreign and domestic literature devoted to the study of amino acid composition of aquatic organisms, representing major groups of producers (green microalgae and diatoms, cyanobacteria) and primary consumers (zooplankton). Based on published data we estimated the composition of essential and nonessential amino acids of microalgae, cyanobacteria, zooplankton, and are determined their differences. It is concluded that the amino acid composition of major groups of plankton is heterogenous. The role of amino acids as a limiting factor for the development of herbivorous zooplankton is discussed. We demonstrated the prospects and the need for further study of amino acid composition in order to develop a complete theory of the functioning of aquatic ecosystems. 
Таблица 1. Сравнительный состав незаменимых аминокислот микроводорослей и цианобактерий (\% от суммы АК)

\begin{tabular}{|c|c|c|c|c|c|c|c|c|c|c|}
\hline $\begin{array}{l}\text { Таксономичес } \\
\text { кое название }\end{array}$ & Условия & Вал & Иле & Лей & Фен & Лиз & Met & Tpe & Гис & $\begin{array}{l}\text { Источни } \\
\kappa \\
\text { данных } \\
\end{array}$ \\
\hline \multirow[t]{5}{*}{ Chlorophyta } & Культура* & 5.5 & 3.4 & 8.8 & 4.6 & 6.5 & 2.2 & 4.8 & 2.1 & {$[5]$} \\
\hline & Культура & 5.4 & 4.5 & 7.5 & 4.2 & - 6.8 & - - & - 5.0 & - 2.5 & [28] \\
\hline & Культура & 6.0 & 4.3 & 8.8 & 5.7 & 7.8 & 2.3 & 5.1 & 2.2 & {$[8]$} \\
\hline & Культура* & 5.8 & 4.3 & 8.8 & 6.1 & 6.5 & 2.5 & 5.5 & 2.0 & [7] \\
\hline & Культура & 5.3 & 3.8 & 7.8 & 4.7 & 5.2 & 2.2 & 4.0 & 1.8 & {$[62]$} \\
\hline$M \pm M$ & & $5.6 \pm 0.1$ & $4.1 \pm 0.2$ & $8.3 \pm 0.3$ & $5.1 \pm 0.4$ & $6.6 \pm 0.4$ & $2.3 \pm 0.1$ & $4.9 \pm 0.3$ & $2.1 \pm 0.1$ & \\
\hline \multirow[t]{6}{*}{ Cyanobacteria } & $\begin{array}{l}\text { Природна } \\
\text { g}^{1}\end{array}$ & 6.2 & 5.8 & 9.5 & 3.6 & 1.9 & 0.2 & 7.1 & 1.4 & {$[34]$} \\
\hline & $\begin{array}{l}\text { Природна } \\
\text { я* }^{*}\end{array}$ & 6.5 & 5.8 & 8.8 & 4.6 & 5.6 & 2.2 & 5.5 & 1.7 & [7] \\
\hline & Культура & 6.2 & 5.2 & 10.0 & 5.8 & 5.1 & 1.6 & 5.2 & 1.7 & [8] \\
\hline & Культура* & 6.0 & 4.6 & 8.9 & 4.3 & 5.2 & 1.7 & 5.5 & 1.6 & [5] \\
\hline & Культура* & 6.6 & 6.0 & 9.3 & 5.0 & 5.0 & 2.3 & 5.4 & 1.5 & [7] \\
\hline & & $6.8 \pm 0.5$ & $5.1 \pm 0.4$ & $10.1 \pm 0.8$ & $4.0 \pm 0.7$ & $4.1 \pm 0.7$ & $1.4 \pm 0.4$ & $5.5 \pm 0.4$ & $1.4 \pm 0.2$ & \\
\hline \multirow[t]{6}{*}{ Bacillariophyta } & $\begin{array}{l}\text { Природна } \\
\operatorname{q}^{1}\end{array}$ & 3.9 & 5.1 & 8.8 & 5.1 & 5.1 & 1.4 & 5.3 & 1.2 & [34] \\
\hline & $\begin{array}{l}\text { Природна } \\
\text { Я̆ }^{2}\end{array}$ & 5.0 & 5.1 & 8.8 & 3.9 & 5.3 & 0.6 & 6.8 & 0.9 & [41] \\
\hline & $\begin{array}{l}\text { Природна } \\
g^{3}\end{array}$ & 6.9 & 3.8 & 6.9 & 3.1 & 11.5 & 0.8 & 7.6 & 0.8 & [41] \\
\hline & Культура & 6.2 & 6.6 & 9.3 & 6.7 & 7.2 & - & 5.6 & 2.5 & {$[28]$} \\
\hline & Культура & 4.0 & 4.5 & 2.6 & 6.3 & 8.0 & 5.0 & 6.5 & - & [42] \\
\hline & Культура & 4.8 & 4.4 & 6.7 & 4.6 & 6.1 & 3.3 & 4.6 & 1.0 & [62] \\
\hline
\end{tabular}




\begin{tabular}{|c|c|c|c|c|c|c|c|c|c|c|}
\hline & Культура* & 5.0 & 4.9 & 7.9 & 6.2 & 6.7 & 2.3 & 4.7 & 2.3 & [14] \\
\hline$M \pm M$ & & $5.2 \pm 0.4$ & $4.8 \pm 0.3$ & $7.8 \pm 0.9$ & $5.2 \pm 0.5$ & $71 \pm 0$ & $2.2 \pm 0.6$ & $5.8 \pm 0.4$ & $1.5 \pm 0.2$ & \\
\hline
\end{tabular}

* - Даны усредненные значения, ${ }^{1}$ - оз. Касумигаура, ${ }^{2}$ - пруд Бугач, ${ }^{3}$ - пруд Лесной 
Таблица 2. Сравнительный состав заменимых аминокислот микроводорослей и цианобактерий (\% от суммы АК)

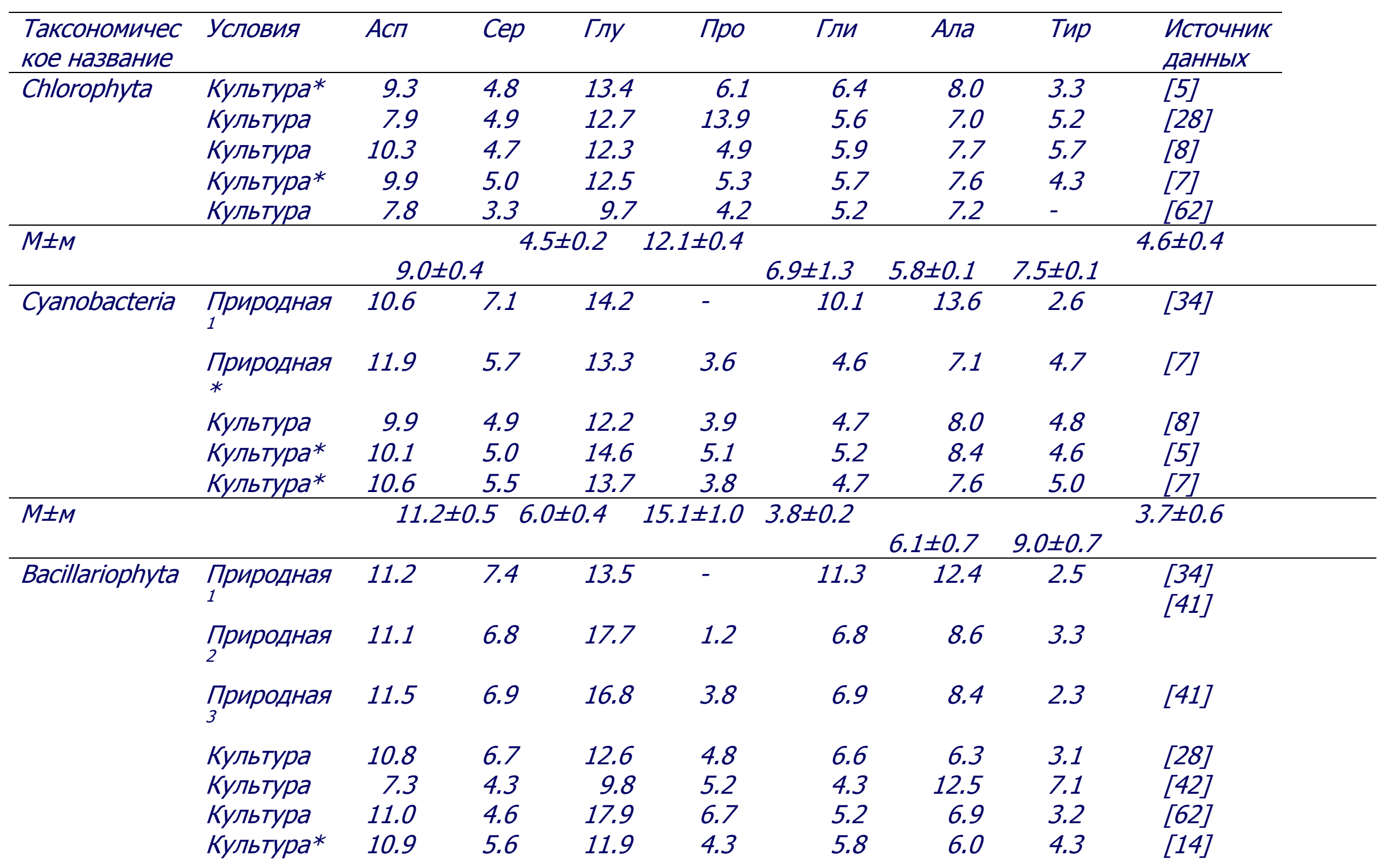




\begin{tabular}{lccccccccc} 
& Культура & 10.4 & 4.6 & 12.7 & 3.3 & 5.5 & 7.3 & 3.7 & {$[12]$} \\
\hline$M \pm M$ & $10.5 \pm 0.3$ & $5.9 \pm 0.4$ & $14.1 \pm 0.9$ & $4.2 \pm 0.4$ & & & $3.7 \pm 0.4$ & \\
\hline
\end{tabular}

* - Даны усредненные значения, ${ }^{1}$-оз. Касумигаура, ${ }^{2}$ - пруд Бугач, ${ }^{3}$ - пруд Лесной 
Таблица 3. Сравнительный состав незаменимых аминокислот зоопланктона (\% от суммы АК)

\begin{tabular}{|c|c|c|c|c|c|c|c|c|c|c|}
\hline Вид & $\begin{array}{l}\text { УСЛОв } \\
\text { ия }\end{array}$ & Вал & Иле & Лей & Фен & Лиз & Мет & Tpe & Гис & $\begin{array}{l}\text { Источн } \\
\text { ик } \\
\text { данны } \\
x \\
\end{array}$ \\
\hline Daphnia carinata & $\Pi$ & 6.3 & 5.0 & 10.1 & 4.9 & 6.5 & 2.8 & 5.5 & 3.2 & {$[43]$} \\
\hline Moina australiensis & $\Pi$ & 6.8 & 5.1 & 9.5 & 5.1 & 6.4 & 2.2 & 5.3 & 2.6 & {$[43]$} \\
\hline $\begin{array}{l}\text { Euterpina } \\
\text { acutifrons }\end{array}$ & $\Pi$ & 5.4 & 4.9 & 7.0 & 3.3 & 7.5 & - & 4.9 & 2.5 & [29] \\
\hline Eurytemora velox & $\Pi$ & 5.8 & 4.6 & 6.1 & 4.2 & 7.4 & - & 5.9 & 2.6 & {$[16]$} \\
\hline $\begin{array}{l}\text { Calanipeda aquae- } \\
\text { dulcis }\end{array}$ & $\Pi$ & 5.4 & 4.9 & 7.0 & 4.1 & 8.5 & - & 5.2 & 2.5 & [16] \\
\hline $\begin{array}{l}\text { Diacyclops } \\
\text { bicuspidatus }\end{array}$ & $\Pi$ & 5.2 & 4.7 & 6.8 & 3.9 & 8.8 & - & 5.1 & 2.4 & [16] \\
\hline $\begin{array}{l}\text { Acanthocyclopus } \\
\text { robustus }\end{array}$ & $\Pi$ & 5.3 & 4.9 & 6.9 & 3.8 & 8.3 & - & 4.9 & 2.5 & [16] \\
\hline Daphnia pulicaria & $\Pi$ & 5.4 & 4.4 & 6.9 & 4.4 & 8.2 & - & 6.2 & 2.1 & {$[16]$} \\
\hline Daphnia magna & $\Pi$ & 5.3 & 4.5 & 7.1 & 4.3 & 9.3 & - & 5.8 & 2.1 & [16] \\
\hline Moina micrura & Л & 4.8 & 4.5 & 8.6 & 4.1 & 11.6 & 1.2 & 3.2 & 5.5 & {$[54]$} \\
\hline $\begin{array}{l}\text { Diaphanosoma } \\
\text { excisum }\end{array}$ & Л & 6.6 & 2.9 & 8.6 & 4.0 & 10.6 & 2.6 & 4.1 & 2.8 & {$[54]$} \\
\hline $\begin{array}{l}\text { Brachionus } \\
\text { calyciflorus }\end{array}$ & Л & 5.4 & 4.9 & 10.1 & 5.9 & 9.7 & 1.1 & 4.4 & 2.1 & {$[54]$} \\
\hline $\begin{array}{l}\text { Смешанный } \\
\text { зоопланктон }\end{array}$ & $\Pi$ & 4.9 & 4.3 & 7.8 & 4.0 & 14.6 & 2.1 & 4.0 & 2.1 & {$[51]$} \\
\hline Cyclops abyssorum & $\Pi$ & 6.0 & 4.3 & 7.3 & 4.3 & 6.7 & 1.7 & 4.9 & 2.1 & [67] \\
\hline $\begin{array}{l}\text { Diaptomus } \\
\text { cyaneus }\end{array}$ & $\Pi$ & 5.8 & 4.1 & 7.4 & 3.8 & 7.4 & 1.9 & 4.8 & 2.1 & {$[67]$} \\
\hline
\end{tabular}




\begin{tabular}{|c|c|c|c|c|c|c|c|c|c|c|}
\hline Daphnia pulicaria & $\Pi$ & 6.3 & 4.9 & 8.3 & 5.0 & 6.1 & 2.0 & 6.3 & 2.2 & [67] \\
\hline$M \pm M$ & & $\begin{array}{l}5.7 \pm 0 . \\
2\end{array}$ & $\begin{array}{l}4.6 \pm 0 \\
1\end{array}$ & $\begin{array}{l}7.8 \pm 0 . \\
3\end{array}$ & $\begin{array}{l}4.3 \pm 0 \\
2\end{array}$ & $\begin{array}{l}8.6 \pm 0 . \\
6\end{array}$ & $\begin{array}{l}2.0 \pm 0 \\
2\end{array}$ & $\begin{array}{l}5.0 \pm 0 . \\
2\end{array}$ & $\begin{array}{l}2.6 \pm 0 \\
2\end{array}$ & \\
\hline
\end{tabular}

П- природный зоопланктон, Л- лабораторная культура 
Таблица 4. Сравнительный состав заменимых аминокислот водных зоопланктона (\% от суммы АК)

\begin{tabular}{|c|c|c|c|c|c|c|c|c|c|c|}
\hline Вид & Условия & $A C \Pi$ & Cep & Глу & Про & Гли & Ала & Цис & Tир & $\begin{array}{l}\text { Источник } \\
\text { данных }\end{array}$ \\
\hline Daphnia carinata & $\Pi$ & 9.1 & 5.5 & 12.4 & 4.3 & 4.8 & 6.3 & 1.4 & 4.2 & [43] \\
\hline Moina australiensis & $\Pi$ & 9.8 & 5.0 & 12.6 & 4.5 & 5.0 & 7.2 & 1.2 & 4.6 & [43] \\
\hline Euterpina acutifrons & $\Pi$ & 8.8 & 4.9 & 13.9 & 6.0 & 6.5 & 7.9 & - & 6.9 & [29] \\
\hline Eurytemora velox & $\Pi$ & 11.4 & 5.6 & 14.4 & 7.2 & 6.9 & 9.7 & - & 2.9 & {$[16]$} \\
\hline Calanipeda aquae-dulcis & $\Pi$ & 10.9 & 4.7 & 15.4 & 5.2 & 6.4 & 8.4 & - & 4.0 & {$[16]$} \\
\hline Diacyclops bicuspidatus & $\Pi$ & 10.8 & 4.4 & 15.7 & 5.9 & 6.8 & 9.3 & - & 2.5 & {$[16]$} \\
\hline $\begin{array}{l}\text { Acanthocyclopus } \\
\text { robustus }\end{array}$ & $\Pi$ & 10.7 & 4.3 & 16.1 & 5.8 & 6.6 & 9.6 & - & 2.9 & {$[16]$} \\
\hline Daphnia pulicaria & $\Pi$ & 11.3 & 6.2 & 13.8 & 6.4 & 6.6 & 8.2 & - & 3.2 & {$[16]$} \\
\hline Daphnia magna & $\Pi$ & 11.6 & 5.8 & 14.6 & 5.9 & 6.2 & 7.9 & - & 2.7 & {$[16]$} \\
\hline Moina micrura & Л & 10.6 & 3.7 & 16.6 & 3.4 & 4.2 & 2.7 & 3.1 & 3.2 & {$[54]$} \\
\hline Diaphanosoma excisum & Л & 10.9 & 2.8 & 14.5 & 6.9 & 8.3 & 4.7 & 1.3 & 3.4 & {$[54]$} \\
\hline Brachionus calyciflorus & Л & 11.8 & 3.9 & 13.7 & 6.8 & 3.8 & 4.5 & 1.7 & 3.2 & {$[54]$} \\
\hline $\begin{array}{l}\text { Смешанный } \\
\text { зоопланктон }\end{array}$ & $\Pi$ & 8.4 & 4.0 & 14.2 & - & 7.0 & 8.1 & - & 5.8 & {$[51]$} \\
\hline Cyclops abyssorum & $\Pi$ & 9.3 & 4.5 & 13.4 & 5.5 & 6.1 & 8.2 & 1.4 & 7.6 & {$[67]$} \\
\hline Diaptomus cyaneus & $\Pi$ & 9.0 & 4.5 & 13.1 & 5.8 & 5.6 & 9.1 & 1.4 & 8.2 & {$[67]$} \\
\hline Daphnia pulicaria & $\Pi$ & 10.4 & 5.7 & 13.4 & 5.3 & 5.3 & 6.4 & 1.0 & 4.8 & {$[67]$} \\
\hline$M \pm M$ & & $\begin{array}{l}10.3 \pm 0 \\
2\end{array}$ & $\begin{array}{l}4.7 \pm 0 . \\
2\end{array}$ & $\begin{array}{l}14.2 \pm 0 \\
2\end{array}$ & $5.7 \pm 0.2$ & $\begin{array}{l}6.0 \pm 0 \\
2\end{array}$ & $\begin{array}{l}7.4 \pm 0 \\
4\end{array}$ & $\begin{array}{l}1.6 \pm 0 \\
2\end{array}$ & $\begin{array}{l}4.4 \pm 0 \\
4\end{array}$ & \\
\hline
\end{tabular}

П- природный зоопланктон, Л- лабораторная культура 